74.

$$
\text { MRIによる胆管の } 3 \text { Dイメージ構築の試み }
$$

\title{
Constructing 3D-image of bile ducts (MR-Cholangiography)
}

\author{
国立大阪病院放射線科○下井 睦男 \\ 国井 秀郎 \\ Mustuo.Shimoi \\ シーメンス旭メティテック \\ （株）水内 宣夫 \\ Hideo.Kunii \\ Nobuo.Mizuuchi \\ 白河 豊美 \\ Toyomi.Shirakawa
}

【目的】PSIFシーケンスにおいて、SSFP(Steady State Free Precession)状態になるようにTRを極端に短 く暑ると、静止状態の液体は大きな信号となる。その信号からは強いT2強調像が得ることができ る。このシーケンスを用い拡張した胆管の3次元構築を試みたので、その方法について報告する。

【方法】使用機種は、Siemens社製MAGNETOM H15(1.5T)を用い 撮像シニケンスは、2D-PSIF法、3D-PSIF法を使用した。図1に撮 像条件示す。

(Flow-in-effectについて)：Flow-in-effectによる血流のアーチファ クトが画像にどのような影警を及はすのか、その傾向をファントム 実験および実際の撮像にて検討した。用いたファシトムは、オイル を满たしたボり容器の内腔を通るように、長さ $20 \mathrm{~m}$,内径 $6 \mathrm{~mm} の ヒ ゙$ ニールチューブを固定し、その一端を水道水を满たした容器に接 続、もう二端に流量計を取付けた自作ファントを使用した。测定 は、流速を、0から䄪 $1.2 \mathrm{~cm} / \mathrm{sec}$ 変化させ、その流量に於けるビ ニールチューブ内の水の信号強度を测定した。

(撮像方法)：TR,TE,Flip angleは2D,3D法共に同一条件を用いた。 Slise厚は、2Dが6 mmで每回の呼吸停止の誤差を少なくするため1 $\mathrm{mm}$ のオーバーラップさせた。3Dは、32 mmを 8 分割することで 実効Slise厚を $4 \mathrm{~mm}$ で行った。また、3 D撮像に於ける折り返し アーチフフクトの影響を考虑し、有效断面が連続するように、式 バーラップを設けた。この条件下で、肝缄全体を前積面で撮像し た。この画像を Maximum Intensity Projection (MIP) 法で画像処理を 行い3次元構築をおこなった。

【結果、考察】図 2 にフフントム実験の結果を示す。この実験から 流速が速くなるほど信号は弱くなり、また大きなアーチフアクト は、認められなっかた。わすかな流速の変化で、信号強度は、急激 に低下する傾向にある。これは、血流など撮像領域内を移動するも のに対してSSFPが成立しない為と考える。

図 3 に症例の前類面像を示す。胆管は、高信号に描出されている が、血管系は描出されていない。又、心臓の動きによるアーチファ ク方とイスレベルの信号強度となっている。

図 4 に肝門部閉塞の症例像を示す。左に経皮経肝胆管ドレナージ 像 (PTBD像) 右にMRC (MR-Cholangiogrphy) 像を示す。図 5 は、胆管の解剖学的な位置関係を立体的に把握するためにステレオ 視出来るように画像処理を行っている。さらに、シネ表示すること で閉塞部位も容易に把握できる。

閉塞性黄疸に対してPTCDを施行する場合、事前にその閉塞部位 を知ることは臨床上有用である。その方法としてCT、超音波など の検査法がある。しかしそれらの画像は断面像しか描出されない。 この方法は、直接胆管造影法に匹敵する画像を非侵銥的に得ること ができる有用な検査法である。

【結語】血流のFlow-in-effectによる大きなアーチファクトは認めら れず、血管系は描出されなかった。胆管系のみが描出され、MIP法 を用いる事により直接胆管造影法に匹敵する3 次元投影像が得られ た。

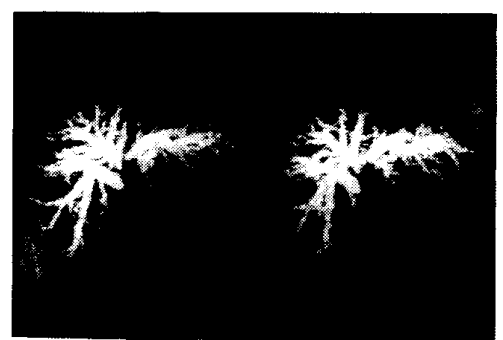

図 5

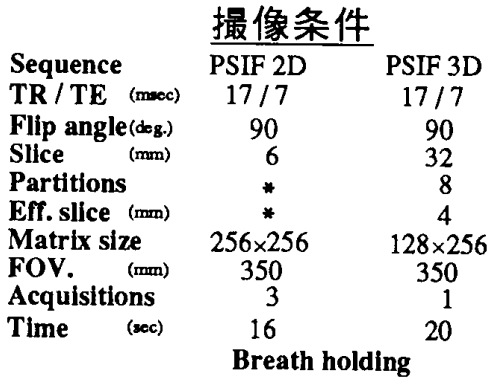

図 1

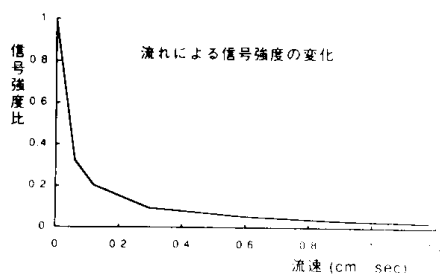

図 2

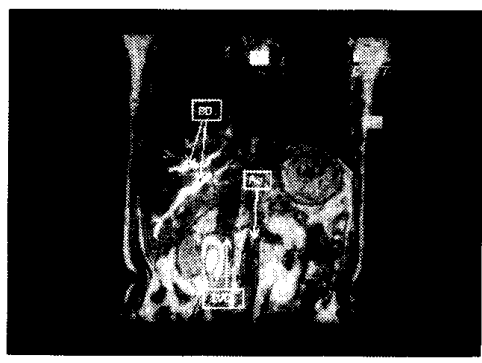

図 3

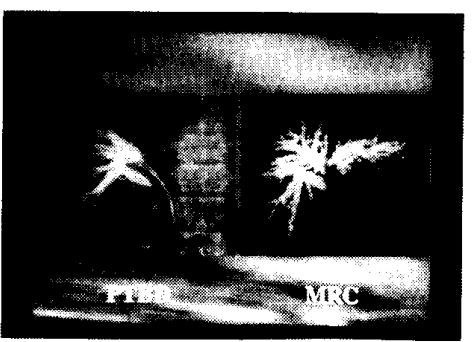

図 4 